\title{
SSR Marker-Based Molecular Characterization of Some Upland Taro (Colocasia esculenta L. Schott) Cultivars of North-East India
}

\author{
Khatemenla $^{1 *}$, S. Alam ${ }^{1}$, Madhumita Barooah ${ }^{2}$, Deepa B. Phookan ${ }^{1}$, \\ Prakash Kalita $^{3}$, Madhumita C. Talukdar ${ }^{1}$ and Star Luikham ${ }^{4}$ \\ ${ }^{1}$ Department of Horticulture, ${ }^{3}$ Department of Crop Physiology, ${ }^{4}$ Department of Plant \\ Pathology, Assam Agricultural University, Jorhat-785013, India \\ ${ }^{2}$ Department of Agricultural Biotechnology, Assam Agricultural University, \\ Jorhat-785013, India \\ *Corresponding author
}

\section{A B S T R A C T}

Ten SSR markers were used to characterize 22 taro cultivars from North East India. The study revealed that the SSR primers like uq201-302, Ce1 B03 and Ce1 C06 with

\section{Keywords}

Taro, cultivars,

SSR, molecular and markers

Article Info

Accepted:

17 May 2019

Available Online:

10 June 2019 $\mathrm{PIC}=0.82,0.76$ and 0.76 respectively were found to be the most informative markers which can be used for future molecular works on taro. The Jaccard's similarity coefficient analysis ranging from 0.103 to 0.89 presented high level of genetic distance as no true duplicates were detected. The dendrogram constructed categorized the cultivars into two main clusters I and II. Only one cultivar, Damor Dema collected from Assam clustered on its own in cluster I and the second cluster II contained the remaining 21 cultivars. It was also observed that geographical origin of the cultivars did not bear any relationship with the molecular classification. The study revealed that cross between genetically distantly related cultivars like Damor Dema and Garo Kochu; Sree Kiran and Makhuti; and Damor Dema and Bor Kochu are advisable. However, crosses between genetically closely related cultivars like Boga Ahina and Red Garo, will have to be avoided for future breeding programme. Characterization of taro cultivars using SSR markers would contribute to the knowledge of genetic relationships between different cultivars.

\section{Introduction}

Taro (Colocasia esculenta L. Schott.) is an ancient and important tuber crop belonging to the monocotyledonous family, Araceae. Worldwide production is on the increase with 10.13 million ton/annum (FAOSTAT, 2016). Molecular data are useful in cases where morphological characters alone are insufficient for the delineation of clear taxonomic groups. The similarity of common names and lack of obvious phenotypic variation among many taro accessions has often led scientists to suspect a high degree of genetic relatedness. This underscores the importance of the estimation of the genetic diversity within germplasm collections (Greene and Pedersen, 1996). Such 
limitations have resulted in the increased use of molecular approaches in assessing genetic diversity (Karp et al., 1997), and in particular the emergence of polymerase chain reaction (PCR)-based markers. DNA markers with high levels of polymorphism permit fine-scale genetic characterization of germplasm if distributed throughout the genome (Okpul et al., 2005). In addition they avoid the complications of environmental effects.

Microsatellites are DNA sequences composed of a tandem repetition of a simple short sequence, occurring in the genome of many higher organisms. Multiple allelic length variants can be identified at most microsatellite loci. Microsatellite markers are highly polymorphic, co-dominant loci and are abundant in most of species genomes (Palapala, 2016). Previously, other researchers had used DNA fingerprinting techniques such as amplified fragment length polymorphism (AFLP) primers (Quero-Garcia et al., 2004) and random amplified polymorphic DNA (RAPD) primers (Singh et al., 2012) to characterize taro. However, SSR primers were regarded to be advantageous over AFLP and RAPD (Hamza, 2004) because PCR-based SSR markers are very powerful as they are co-dominant and multiallelic as well as highly polymorphic.

North East India is one of the centres of origin of colocasia and a considerable level of diversity is expected among the taro cultivars. Though a good amount of molecular work has been carried out in the Pacific and South-East Asian gene pools, very less systemic studies have been carried out in colocasia in North East India. In addition to these, DNA finger printing will prevent the loss of our indigenous germplasm. It will be an immense contribution towards the food security of poor people, if we could select a high yielding colocasia variety suitable for North East India.

\section{Materials and Methods}

\section{Site of cultivar collection}

Taro cultivars were collected in the form of corms and cormels from farmers fields. The taro cultivars were collected from four states of North-East India (Assam, Meghalaya, Arunachal and Nagaland) with focus on potential production areas. Two of the cultivars were also obtained from Central Tuber Crops Research Institute at Thiruvananthapuram, Kerela- India (Table 1).

\section{Details of the experiment}

The twenty-two taro cultivars collected were then planted in Experimental Farm, Department of Horticulture, Assam Agriculture University, Jorhat-Assam in randomized block design (RBD) with three replications maintaining a spacing of $0.60 \mathrm{~m} \mathrm{x}$ $0.45 \mathrm{~m}$. The proper recommended cultivation practices were followed to raise a good crop.

\section{Molecular characterization}

The tender young leaves were harvested in the morning hours from each taro cultivar for extraction of genomic DNA.

\section{Deoxyribonuclic acid (DNA) extraction}

The DNA extraction was performed following the protocol given by Sharma et al., (2008) with slight modification. Young leaf tissues (300 mg) were ground to a fine powder using liquid nitrogen. All the samples were transferred to $2.0 \mathrm{ml}$ eppendorf tubes, $5 \mu \mathrm{L}$ Proteinase K $(10 \mathrm{mg} / \mathrm{ml})$ was added. The tube was incubated in $37^{\circ} \mathrm{C}$ for $30 \mathrm{~min}$ and then at $65^{\circ} \mathrm{C}$ for another $30 \mathrm{~min}$ with frequent swirling. Samples were centrifuged at $8,000 \mathrm{~g}$ for $10 \mathrm{~min}$ at RT and supernatant was transferred to fresh eppendorf tube. Equal volume of phenol: chloroform: isoamyl 
alcohol $(25: 24: 1)$ were added and mixed by gentle inversion for 30-40 times. The samples were centrifuged at $8,000 \mathrm{~g}$ for $10 \mathrm{~min}$ at RT and supernatant was transferred to a fresh tube. $200 \mu \mathrm{L}$ of $2 \mathrm{M} \mathrm{NaCl}$ solutions containing 4\% PEG was added. It was observed that addition of this solution and incubation of the samples for at least $15 \mathrm{~min}$ at $4^{\circ} \mathrm{C}$ increased the recovery of DNA yield. The samples were centrifuged at 8,000 $\mathrm{g}$ for $10 \mathrm{~min}$ at RT. The supernatant was transferred to a fresh tube and precipitated with 2/3 volume of isopropanol. The precipitated nucleic acids were collected and washed twice with wash solution. The obtained nucleic acid pellet was air-dried until the ethanol was removed and dissolved in appropriate amount of TE buffer $(50-70 \mu \mathrm{L})$. The nucleic acid dissolved in TE buffer were treated with ribonuclease (RNase-10 $\mathrm{mg} / \mathrm{ml}$ ), incubated at $37^{\circ} \mathrm{C}$ for $30 \mathrm{~min}$ and stored at $20^{\circ} \mathrm{C}$ until use. The purified DNA was visualized under UV light after electrophoresis using $0.5 \%(\mathrm{w} / \mathrm{v})$ agarose gel and quantified using UV spectrophotometer. The concentration and purity of the extracted DNA were determined using a protein nucleic acid analyzer. The concentration of each DNA sample was adjusted to $20 \mathrm{ng} / \mu \mathrm{L}$, and the samples were stored at $-20^{\circ} \mathrm{C}$ until analysis.

A total of ten SSR primers were screened. PCR amplification were carried out on thermal cycler in a final volume of $10 \mu \mathrm{l}$ containing $1 \mu \mathrm{l}$ template DNA, $1 \mu \mathrm{l} 10 \mathrm{X}$ TB buffer, $0.5 \mu \mathrm{l}$ dNTPs, $0.5 \mu 1 \mathrm{MgCl}_{2}, 0.5 \mu \mathrm{l}$ each of forward and reverse primers, $0.2 \mu \mathrm{l}$ Taq polymerase and $5.8 \mu \mathrm{H}_{2} \mathrm{O}$. The SSR profiles had an initial denaturation at $94^{\circ} \mathrm{C}$ for five minutes, followed by 35 amplification cycles (denaturation at $94^{\circ} \mathrm{C}$ for 1 minute, annealing ranging from 45 to $52^{\circ} \mathrm{C}$ for $1 \mathrm{~min}$ and extension at $72^{\circ} \mathrm{C}$ for 1 minute) and a final extension step at $72^{\circ} \mathrm{C}$ for 7 minute (Table 2). Ten microlitre of amplified PCR product was separated through gel electrophoresis on $3 \%$ agarose gel stained with ethidium bromide and photographed with Digital Imaging System.

\section{Data analysis}

The bands obtained were scored ' 1 ' for presence and ' 0 ' for absence in DNA samples amplified to create a binary data matrix. Polymorphism information content (PIC) of each marker was calculated using the formula:

$\mathrm{PIC}=1-\Sigma \mathrm{x}^{2} \mathrm{i}$

Where, $x i$ is the frequency of $i^{\text {th }}$ allele for each SSR locus. Similarity index were calculated employing Jaccard's coefficient to established genetic relatedness. Molecular weight of the amplified bands was determined based on their relative migration in comparison to the molecular weight standards and expressed in base pairs (bp). Genetic similarity (GS) matrix between accessions based on molecular data was computed using Jaccard's (1908) coefficient. The similarity matrix was used to produce an agglomerative hierarchical clustering by employing Unweighted Pair Group Method with Arithmetic Averages (UPGMA) with average linkage (Sneath and Sokal 1973), which was then graphically converted into a dendrogram.

\section{Results and Discussion}

\section{Molecular characterization of taro cultivars}

Twenty-two cultivars of taro were subjected to molecular analysis using Simple Sequence Repeat (SSR) primer and were compared at genetic level. The data from the banding pattern of all the cultivars with ten polymorphic SSR markers were analysed and a total of sixty-one (61) scorable amplicons 
were produced at an average of 6.1 alleles per locus. Band sizes amplified by the markers are presented in Table 3. The overall size of amplified product ranged from $129 \mathrm{bp}$ to 875bp (Table 3).

Primer uq201- 302 produced the highest number of amplified fragments whereas primer uq84-207 produced the lowest number of amplified fragments (Table 3). All the ten primers showed considerable variation and a total of fourty-nine (49) polymorphic fragments were produced. The highest polymorphism $(100 \%)$ was found in two primers i.e. Ce1 F04 and uq84-207, where the most common band size was 406bp (ranging from 138-424 bp) and 257bp (ranging from 165-268 bp) respectively. On the other hand, the lowest polymorphism $(60 \%)$ was detected in primer uq201- 302 where the common band size was 250bp (ranging from 129-610 bp) (Table 3).

All the markers were very informative with polymorphic information content (PIC) ranging from 0.41 to 0.82 (Table 3 ). The SSR primer uq201- 302 was the most informative marker (PIC=0.82) while uq84-207 was the least informative primer $(\mathrm{PIC}=0.41)$ because PIC value close to one (1) is considered to be more informative (Table 3; Fig. 1 and 2).

Jaccard's similarity coefficient was used to generate a dendrogram using UPGMA cluster analysis (Fig. 4). Based on the similarity coefficient, analysis of twenty-two taro cultivars presented high level of genetic distance. Jaccard's similarity coefficient showed no true duplicates and it ranged from 0.103 (between Damor Dema and Garo) and 0.89 (between Red Garo and Boga Ahina), indicating sufficient genetic variability among the cultivars under study (Fig. 4).

The dendrogram constructed based on UPGMA analysis categorized the twenty-two cultivars into two main clusters I and II (Figure 3 and Table 4). Only one cultivar, Damor Dema collected from Goalpara-Assam clustered on its own in the main cluster I (CLI).

The second main cluster (CL-II) contained the remaining twenty-one (21) cultivars from both North-East and South India and it was further sub-divided into six sub-clusters i.e. A, B, C, D, E, F and G (Fig. 3 and Table 4). Cultivars 'Kaka' collected from Assam and 'Garo' collected from Meghalaya were grouped under cluster A.

The largest sub-cluster i.e. cluster B consisted of six (6) cultivars viz. Makhuti, Ghoti, Boga Ahina, Koni and AAU-Col-46 collected from different districts of Assam and cultivar Red Garo collected from Meghalaya (Fig. 3 and Table 4).

Sub-cluster ' $C$ ' which is the second largest sub-cluster contained four cultivars i.e. Bor, Panch Mukhi and JCC-31 (Fig. 3 and Table 4) collected from different parts of Assam and cultivar Naga collected from Nagaland.

The cultivar Arunachal-2 collected from Arunachal Pradesh was placed alone under cluster D (Fig. 3 and Table 4). Four (4) cultivars collected from different parts of Assam namely Karbi Anglong, Takali, AAUCol-5 and Ahina were categorized under the sub-cluster E (Fig. 3 and Table 4).

The cluster II further sub-divided into clusters $F$ and $G$ which contained two cultivars each viz. AAU-Col-32 and AAU-Col-39 from Assam; and Sree Kiran and Muktakesh from Kerela respectively.

No two cultivars analyzed in the present study showed a similarity coefficient value of one thereby indicating their distinctness (Fig. 3 and 4). 
Table.1 Place of taro cultivar collection

\begin{tabular}{|c|c|c|c|}
\hline Sl. No. & Cultivars & State & District \\
\hline $\mathbf{1 .}$ & Kaka & Assam & Jorhat \\
\hline $\mathbf{2 .}$ & Garo & Meghalaya & Resubelpara- North Garo Hills \\
\hline $\mathbf{3 .}$ & Makhuti & Assam & Kokrajhar \\
\hline $\mathbf{4 .}$ & Ghoti & Assam & Jorhat \\
\hline $\mathbf{5 .}$ & Boga Ahina & Assam & Jorhat \\
\hline $\mathbf{6 .}$ & Koni & Assam & Jorhat \\
\hline $\mathbf{7 .}$ & Red Garo & Meghalaya & Garobadha- West Garo Hills \\
\hline $\mathbf{8 .}$ & Karbi Anglong & Assam & Karbi Anglong \\
\hline $\mathbf{9 .}$ & Bor Kochu & Assam & Dibrughar \\
\hline $\mathbf{1 0 .}$ & AAU-Col-46 & Assam & Karbi Anglong \\
\hline $\mathbf{1 1 .}$ & Arunachal 2 & Arunachal & Pasighat \\
\hline $\mathbf{1 2 .}$ & Panch Mukhi & Assam & Jorhat \\
\hline $\mathbf{1 3 .}$ & Naga & Nagaland & Mokokchung \\
\hline $\mathbf{1 4 .}$ & JCC-31 & Assam & Karbi Anglong \\
\hline $\mathbf{1 5 .}$ & Damor Dema & Assam & Goalpara \\
\hline $\mathbf{1 6 .}$ & AAU-Col-5 & Assam & Karbi Anglong \\
\hline $\mathbf{1 7 .}$ & Ahina & Assam & Jorhat \\
\hline $\mathbf{1 8 .}$ & AAU-Col-32 & Assam & Karbi Anglong \\
\hline $\mathbf{1 9 .}$ & Takali & Assam & Jorhat \\
\hline $\mathbf{2 0 .}$ & AAU-Col-39 & Assam & Karbi Anglong \\
\hline $\mathbf{2 1 .}$ & Muktakesh & Kerela & CTCRI- Thiruvananthapuram \\
\hline $\mathbf{2 2}$. & Sree Kiran & Kerela & CTCRI- Thiruvananthapuram \\
\hline
\end{tabular}

Table.2 Taro SSR-marker and their sequences used to study

\begin{tabular}{|c|c|c|c|}
\hline $\begin{array}{c}\text { Primer } \\
\text { name }\end{array}$ & Forward primers & Reverse primers & $\begin{array}{l}\text { Temperatur } \\
\text { e }\left({ }^{\circ} \mathrm{C}\right)\end{array}$ \\
\hline Ce1 A06 & 5'-GCT TGT CGG ATC TAT TGT- 3' & 5'-GGA ATC AGT AGC CAC ATC-3' & 51 \\
\hline Ce1 B03 & 5'- TTG CTT GGT GTG AAT G-3' & 5'- CTA GCT GTG TAT GCA GTG T-3' & 51 \\
\hline Ce1 C03 & 5’- TGT TGG GAA AGA GGG-3’ & 5'- GGG GAA TAA CCA GAG AA-3' & 51 \\
\hline Ce1 C06 & 5'- CCA GAA GAG ACG TTA CAG A-3' & 5’- ACG ACT TTG GAC GGA-3’' & 47 \\
\hline Ce1 F04 & 5'- AGG GAA TAC AAT GGC TC-3' & 5'- ACG AGG GAA GAG TGT AAA-3' & 47 \\
\hline Ce1 H12 & 5'- TAG TTA GCG TGC CTT TC-3' & 5'- CAA CAA CTT AAT GCT TCA C- 3 & 51 \\
\hline uq73-164 & $\begin{array}{l}\text { 5'- ATG CCA ATG GAG GAT GGC AG- } \\
3 \text {, }\end{array}$ & $\begin{array}{l}\text { 5'- CGT CTA GCT TAG GAC AAC ATG- } \\
3 \text { ' }\end{array}$ & 47 \\
\hline uq84-207 & $\begin{array}{l}\text { 5'- AGG ACA AAA TAG CAT CAG } \\
\text { CAC- } 3 \text { ' }\end{array}$ & $\begin{array}{c}\text { 5'- CCC ATT GGA GAG ATA GAG } \\
\text { AGA- 3' }\end{array}$ & 51 \\
\hline uq97- 256 & $\begin{array}{l}5 \text { '- GTA ATC TAT TCA ACC CCC CTT- } \\
3 \text {, }\end{array}$ & 5'- TCA ACC TTC TCC ATC AGT CC-3' & 49 \\
\hline $\begin{array}{l}\text { uq201- } \\
302\end{array}$ & $\begin{array}{c}\text { 5'- CTA AGG AGA GGA GAT CCG } \\
\text { AAC- } 3 \text { ' }\end{array}$ & 5'- CAA GAC GAT GCT GAA CCA- 3' & 49 \\
\hline
\end{tabular}


Table.3 Polymorphism detected in twenty-two taro cultivars by ten SSR primers

\begin{tabular}{|c|c|c|c|c|c|c|c|}
\hline Primer & $\begin{array}{c}\text { No. of } \\
\text { alleles }\end{array}$ & $\begin{array}{c}\text { Polymorphi } \\
\text { callele }\end{array}$ & \multicolumn{2}{|c|}{ Size of bands (bp) } & Polymorphis & PIC \\
& amplifie & High & Low & $\begin{array}{c}\text { Most } \\
\text { frequent }\end{array}$ & & value \\
& & & & & & & \\
\hline Ce1 A06 & 8 & 6 & 277 & 205 & 205 & 75 & 0.74 \\
\hline Ce1 B03 & 8 & 5 & 250 & 157 & 157 & 62.5 & 0.76 \\
\hline Ce1 C03 & 5 & 4 & 875 & 435 & 523 & 80 & 0.70 \\
\hline Ce1 C06 & 8 & 7 & 857 & 168 & 440 & 87.5 & 0.76 \\
\hline Ce1 F04 & 6 & 6 & 424 & 138 & 406 & 100 & 0.73 \\
\hline Ce1 H12 & 4 & 4 & 237 & 129 & 191 & 75 & 0.59 \\
\hline uq73-164 & 4 & 4 & 531 & 168 & 168 & 75 & 0.67 \\
\hline uq84-207 & 3 & 3 & 268 & 165 & 257 & 100 & 0.41 \\
\hline uq97- 256 & 5 & 4 & 510 & 160 & 305 & 80 & 0.63 \\
\hline uq201- 302 & 10 & 6 & 610 & 129 & 250 & 60 & 0.82 \\
\hline
\end{tabular}

Table.4 List of clustered taro cultivars using UPGMA based on molecular relationship (Jaccard's similarity coefficient)

\begin{tabular}{|c|c|c|c|}
\hline \multicolumn{2}{|c|}{ Cluster } & No. of cultivar & Cultivars \\
\hline \multicolumn{2}{|c|}{ I } & 1 & Damor Dema \\
\hline II & A & 2 & Kaka and Garo \\
\cline { 2 - 4 } & B & 6 & Makhuti, Ghoti, Boga Ahina, Red Garo, Koni and AAU-Col-46 \\
\hline \multirow{4}{*}{ B 1} & 2 & Boga Ahina and Red Garo \\
\hline C & 5 & Bor, Panch Mukhi, JCC-31 and Naga \\
\hline D & 1 & Arunachal-2 \\
\hline E & 4 & Karbi Anglong, Takali, AAU-Col-5 and Ahina \\
\hline F & 2 & AAU-Col-32 and AAU-Col-39 \\
\hline G & 2 & Sree Kiran and Muktakesh \\
\hline
\end{tabular}

Fig.1 DNA extracted from twenty-two taro cultivars visualized under UV-rays (Lane 1-22)

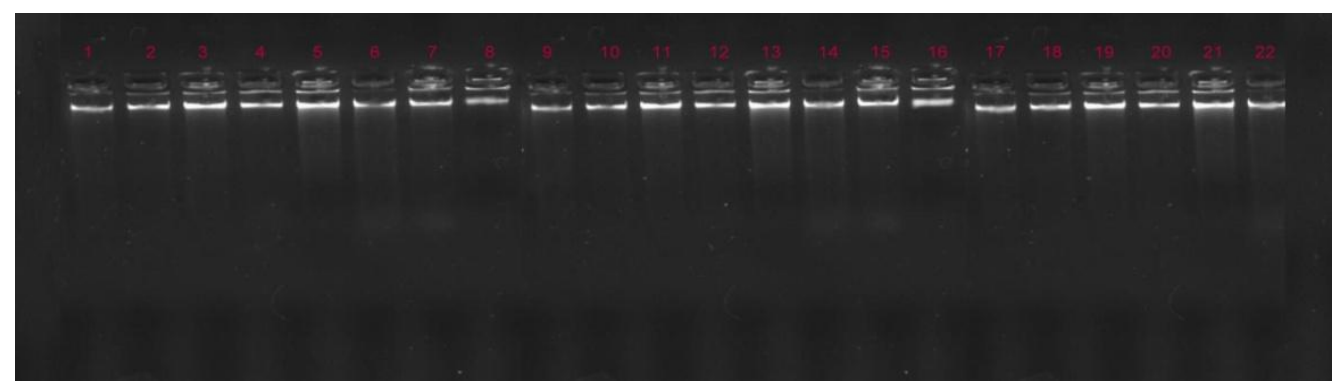

Lane 1- Kaka, 2- Garo, 3- Makhuti, 4- Ghoti, 5- Boga Ahina, 6- Koni, 7- Red Garo, 8- Karbi Anglong, 9- Bor Kochu, 10- AAU-Col-46, 11- Arunachal 2, 12- Panch Mukhi, 13- Naga, 14- JCC-31, 15- Damor Dema, 16- AAUCol-5, 17- Ahina, 18- AAU-Col-32, 19- Takali, 20- AAU-Col-39, 21- Muktakesh and 22- Sree Kiran 
Fig.2 DNA fingerprints of twenty-two taro cultivars amplified with ten SSR primers

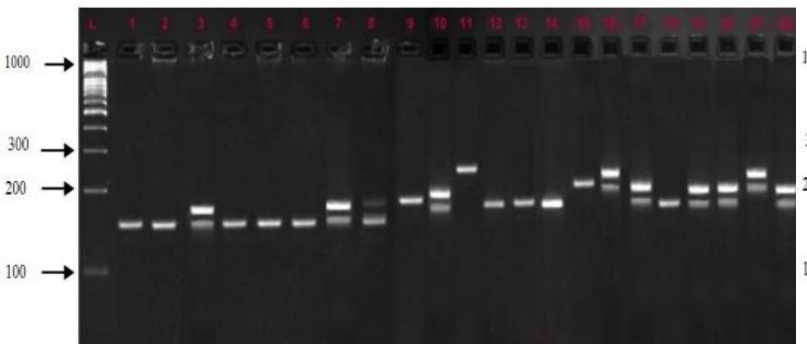

(a) SSR primer Ce1 A06

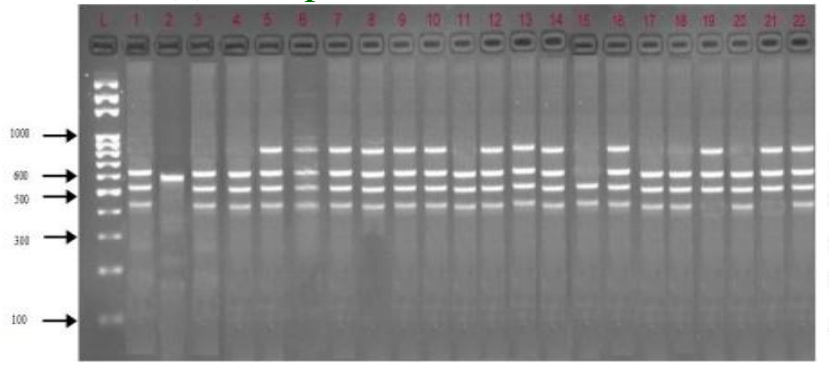

(c) SSR primer Ce1 C03

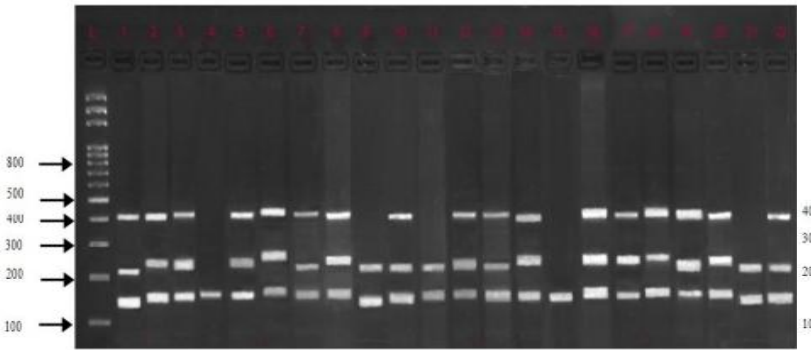

(e) SSR primer Ce1 F04

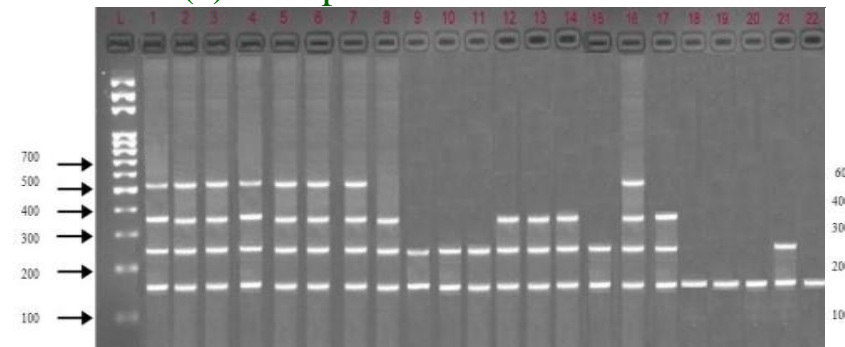

(g) SSR primer Ce1 uq73-164

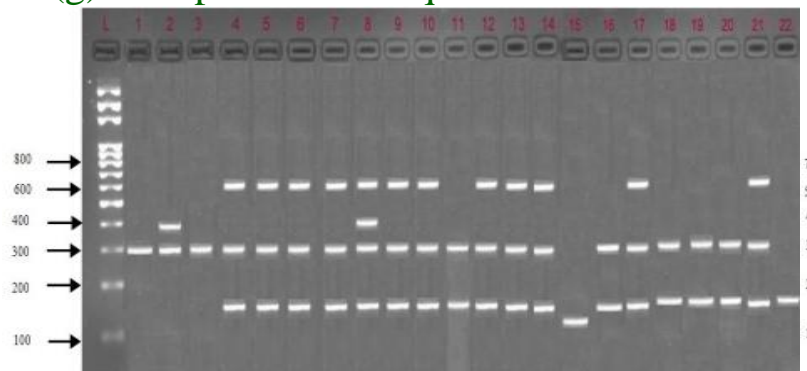

(i) SSR primer Ce1 uq97-256207

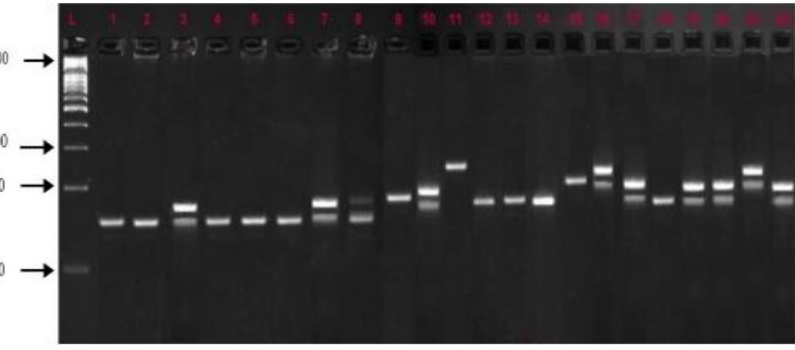

(b) SSR primer Ce1 B03

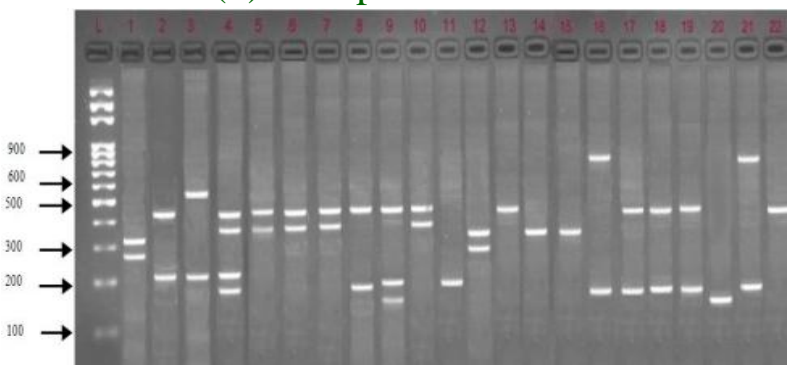

(d) SSR primer Ce1 C06

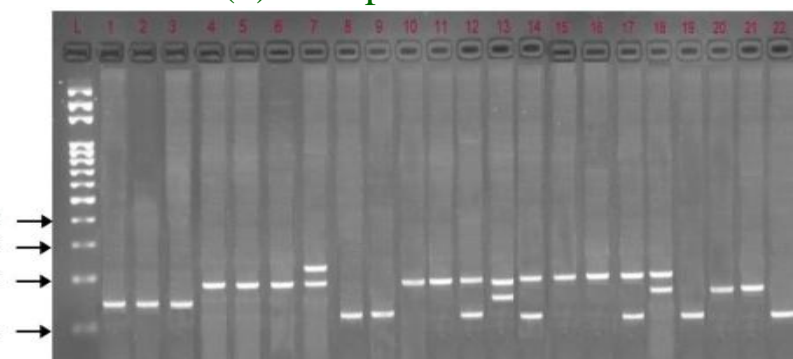

(f) SSR primer Ce1 HI2

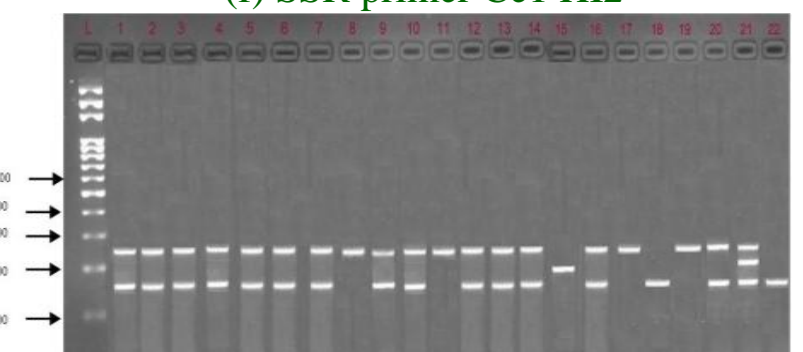

(h) SSR primer Ce1 uq84-207

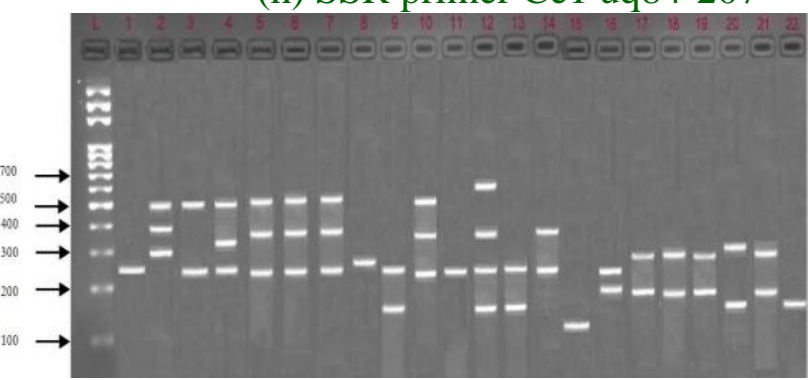

(j) SSR primer Ce1 uq201-302

Lane 1- Kaka, 2- Garo, 3- Makhuti, 4- Ghoti, 5- Boga Ahina, 6- Koni, 7- Red Garo, 8- Karbi Anglong, 9- Bor Kochu, 10- AAU-Col-46, 11- Arunachal 2, 12- Panch Mukhi, 13- Naga, 14- JCC-31, 15- Damor Dema, 16- AAUCol-5, 17- Ahina, 18- AAU-Col-32, 19- Takali, 20- AAU-Col-39, 21- Muktakesh and 22- Sree Kiran 
Fig.3 Upgma dendrogram showing the genetic relationship between twenty-two taro cultivars based on SSR markers

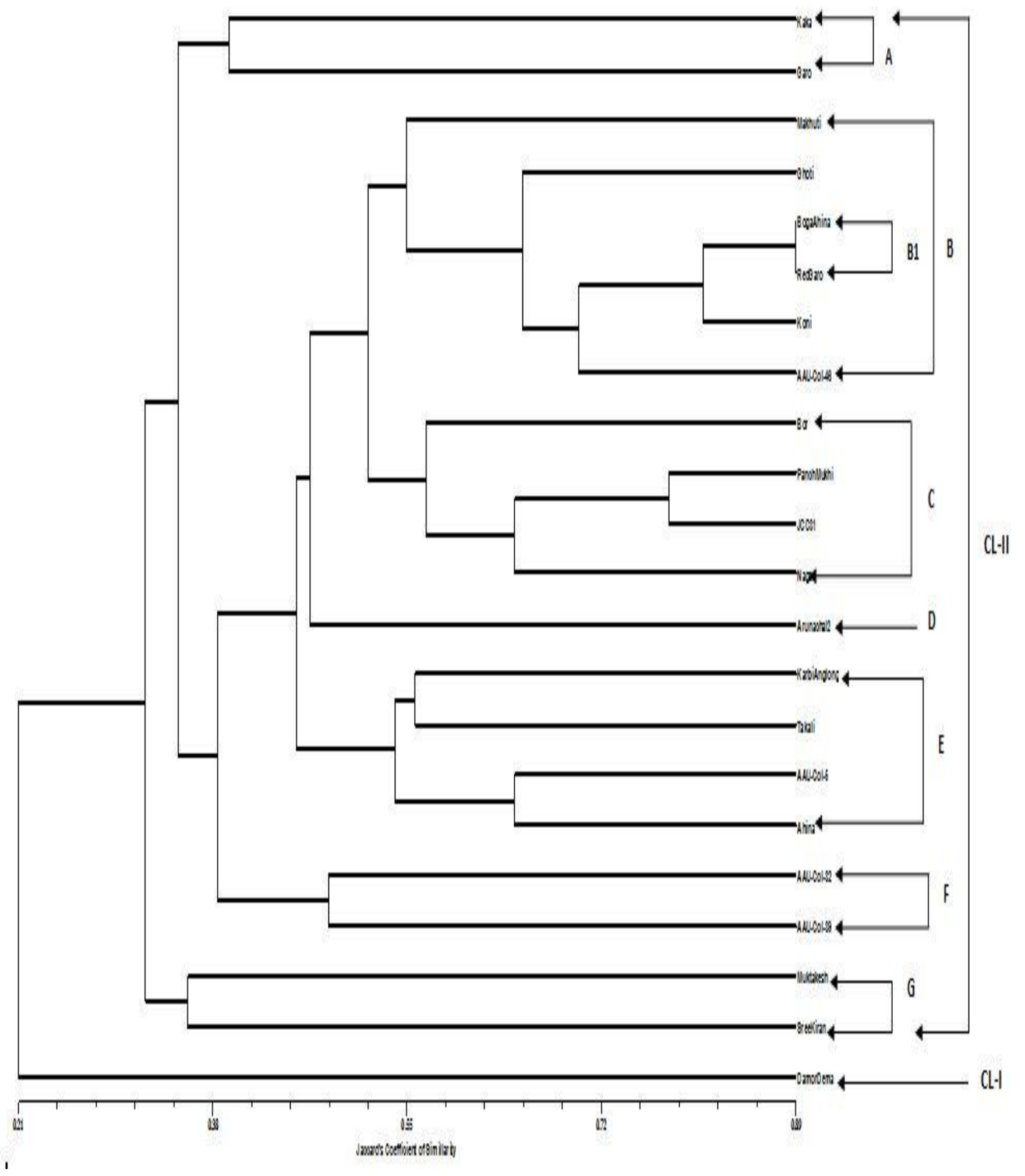


Fig.4 Similarity matrix based on Jaccard's Coefficient of Similarity

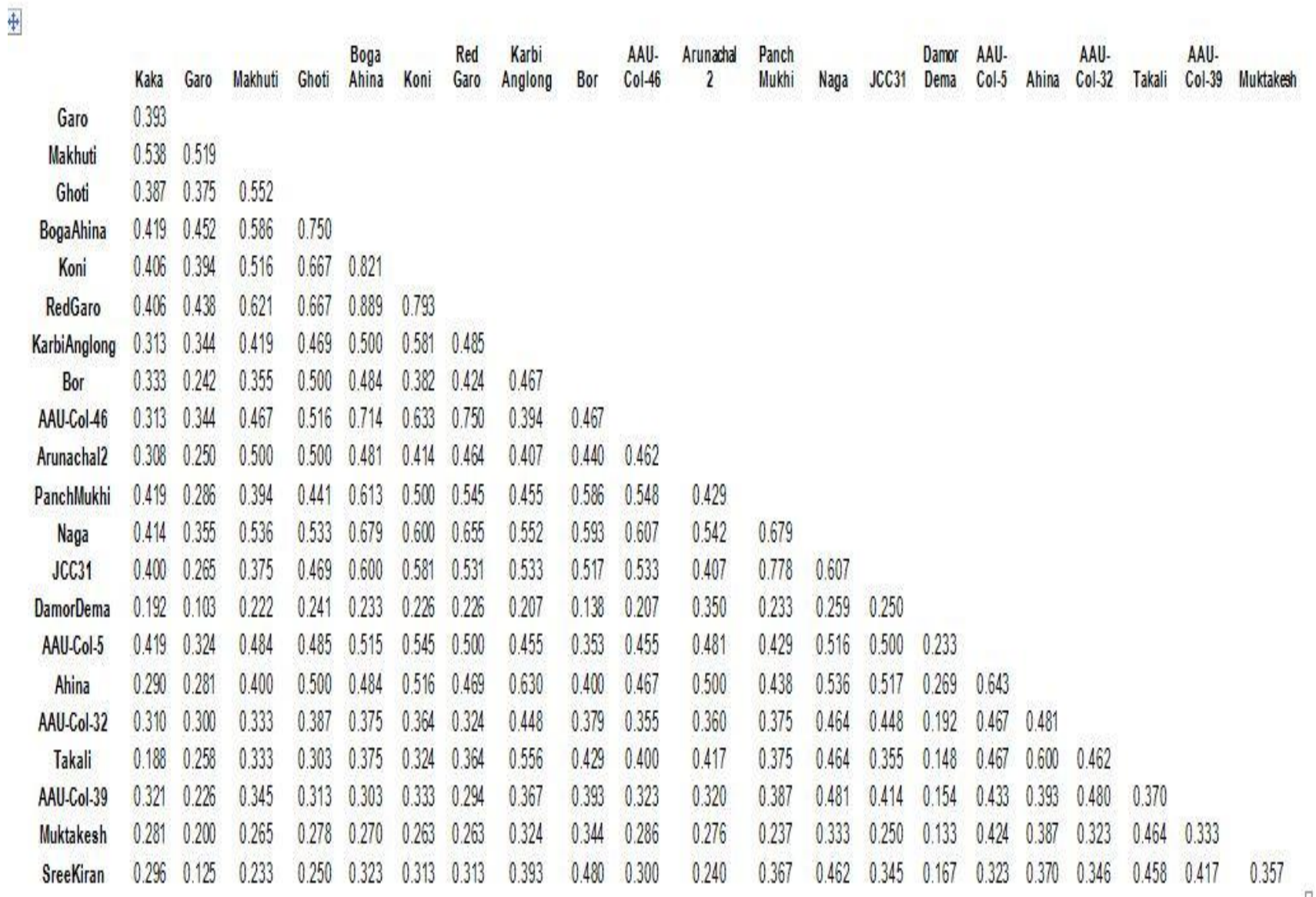

Clustering pattern did not show any strict relationship between geographical and genotypic diversity as the cultivars from different geographic regions were grouped together indicating that the cultivars under investigation were genetically related. Similar results were also reported by previous researchers like Irwin et al., (1998) and Lakhanpaul et al., (2003).

In practical terms, the present result obtained from the SSR characterization revealed that cross between genetically distantly related cultivars like Damor Dema and Garo, Sree Kiran and Makhuti, Damor Dema and Bor, Muktakesh and Damor Dema are advisable. However, crosses between genetically closely related cultivars such as those identified by the SSR analysis like Boga Ahina and Red Garo, will have to be avoided for future breeding programme.

From the study, SSR microsatellite proved to be a valuable tool for cultivar identification especially in such a collection with a narrow genetic base. Results agreed with that of earlier studies by Singh et al., (2008), Mwenye (2009), Faveretto et al., (2011), Macharia et al., (2014) and Palapala et al., (2016).

It is concluded that, among the molecular markers available, SSRs are fast emerging as markers of choice, mostly due to their codominant nature, transferability, reproducibility and amenability to high 
throughput. The current study showed SSR markers are suitable for genetic diversity analysis of Colocasia esculenta (L.) Schott because they showed high level of polymorphism and phylogenetic differentiation with corresponding results. SSR markers like Ce1 F04 and uq84-207 which gave 100 percent polymorphism can be selected for molecular characterization of taro. These primers will be useful for future molecular analysis and will provide taro breeders with a genetic basis for selection of parents for crop improvement.

The taro cultivars were diverse even within their location as they were not grouped according to their geographic origin. The present investigation revealed that crosses between genetically distantly related cultivars like Damor Dema and Garo Kochu; Sree Kiran and Makhuti; Damor Dema and Bor Kochu; and Muktakesh and Damor Dema are advisable. However, crosses between genetically closely related cultivars such as those identified by the SSR analysis like Boga Ahina and Red Garo, will have to be avoided for future hybridization programme. Therefore, characterization of taro cultivars using molecular markers is of prime necessity for plant breeding programmes and exsitu conservation of plant genetic resources.

\section{References}

FAOSTAT. 2016. FAO Statistical Database: Agricultural production of primary crops. Available from http://apps.fao.org/default.htm.

Favoretto, P., Veasey, E. A. and Melo, P. C. T. 2011. Molecular characterization of potato cultivars using SSR markers. Horticultura Brasileira. 29(4): 542-547.

Greene, S. L. and Pedersen, G. A. 1996. Eliminating duplicates from collections. A white clover example. Crop Science. 36:1398-400.
Hamza, S., Hamida, W. B., Rebai, A. and Harrabi, M. 2004. SSR-based genetic diversity assessment among Tunisian winter barley and relationship with morphological traits. Euphytica 135:107-118.

Irwin, S. V., Kaufusi, P., Banks, K., Pena, R and Cho, J. J. 1998. Molecular characterization of taro (Colocasia esculenta) using RAPD markers. Euphytica. 99: 183-189.

Jaccard, P. 1908. Nouvelles researches sur la distribution florale. Bulletin de la Societe vaudoise des sciences naturelles. 44:223-270.

Karp, A., Kresovich, S., Bhat, K.V., Ayad, W. G. and Hodgkin, T. 1997. Molecular tools in plant genetic resources conservation: a guide to the technologies. IPGRI Technical Bulletin No. 2. International Plant Genetic Resources Institute, Rome, Italy.

Lakhanpaul, S., Velayudhan, K. C. and Bha, K.V. 2003. Analysis of genetic diversity in Indian taro [Colocasia esculenta (L.) Schott] using random amplified polymorphic DNA (RAPD) markers. Genetic Resources and Crop Evolution. 50: 603-609.

Macharia, M. W., Runo, S. M., Muchugi, A. N. and Palapala, V. 2014. Genetic structure and diversity of East African taro [Colocasia esculenta (L.) Schott]. African Journal of Biotechnology. 13(29): 2950-2955.

Mwenye, O. J. 2009. Genetic diversity analysis and nutritional assessment of cocoyam genotypes in Malawi. M.Sc thesis submitted to university of the Free State Bloemfontein, South Africa.

Okpul, T., Mace, E. S., Godwin, I. D., Singh, D. and Wagih, M. E. 2005. Evaluation of variability among breeding lines and cultivars of taro (Colocasia esculenta) in Papua New Guinea using ISSR fingerprinting and agro-morphological 
characterization. Plant Genetic Resources Newsletter. 143: 8-16.

Palapala, V. A. P. and Akwee, E. P. 2016. Genetic diversity analysis of Kenyan taro [Colocasia esculenta (L.) Schott] accessions using SSR markers. Sky Journal of Agricultural Research. 5(5):076 - 086.

Quero-Garcia, J., Noyer, J. L., Perrier, X., Marchand, J. L. and Lebot, V. 2004. A germplasm stratification of taro (Colocasia esculenta) based on agromorphological descriptors, validation by AFLP markers. Euphytica. 137:387395.

Singh, D., Mace, E. S., Godwin, I. D.,
Mathur, P. N., Okpul, T. and Taylor, M. 2008. Assessment and rationalization of genetic diversity of Papua New Guinea taro (Colocasia esculenta) using SSR DNA fingerprinting, Genetic Resources and Crop Evolution. 55:811-822.

Singh, S., Singh, D. R., Faseela, F., Kumar, N., Damodaran, V. and Srivastava, R. C. 2012. Diversity of 21 taro (Colocasia esculenta (L.) Schott) accessions of Andaman Islands. Genetic Resources and Crop Evolution. 59(5): 821-829.

Sneath, P. H. A. and Sokal, R. R. 1973. Numerical taxonomy: The principles and practice of numerical classification. San Francisco: W. H. Freeman and Co.

\section{How to cite this article:}

Khatemenla, S. Alam, Madhumita Barooah, Deepa B. Phookan, Prakash Kalita, Madhumita C. Talukdar and Star Luikham. 2019. SSR Marker-Based Molecular Characterization of Some Upland Taro (Colocasia esculenta L. Schott) Cultivars of North-East India. Int.J.Curr.Microbiol.App.Sci. 8(06): 2310-2320. doi: https://doi.org/10.20546/ijcmas.2019.806.274 